\title{
Replication of a 1970s Study on Domestic Sheep Losses to Predators on Utah's Summer Rangelands
}

\author{
Brian C. Palmer, ${ }^{1}$ Michael R. Conover, ${ }^{2}$ and S. Nicole Frey ${ }^{3}$ \\ Authors are ${ }^{1}$ Graduate Student, ${ }^{2}$ Professor, and ${ }^{3}$ Assistant Professor, Department of Wildland Resources, Utah State University, Logan, \\ UT 84322-5230, USA.
}

\begin{abstract}
Lamb losses to predation have historically ranged from $4 \%$ to $8 \%$ in the western United States but most data are over 30 yr old. We repeated a sheep depredation study conducted from 1972 through 1975 on Cedar Mountain, Utah, to determine how predation rates have changed in the last three decades. Pastures and herd sizes were similar (1730 lambs) between our study (2006 and 2007) and the prior one. Additionally, 40\% of the ranchers in our study also participated in the prior study. During 2006 and 2007, 5.8\% of all lambs on Cedar Mountain were lost to all causes compared to 9.5\% during the 1970s. Predators were responsible for $87 \%$ of all verified lamb losses during our study versus $83 \%$ during the 1970 s. We estimated that $4.9 \%$ of all lambs on Cedar Mountain were killed by predators during our study compared to 7.9\% during the 1970s. During our study, coyotes (Canis latrans Say) were responsible for $67 \%$ of the depredated lambs, cougars (Felis concolor Linnaeus) for $31 \%$, and black bears (Ursus americanus Pallas) for 2\%. During the 1970 s, coyotes killed $98 \%$ of all depredated lambs, cougars killed $2 \%$, and bears killed $0 \%$. In addition to the increase in cougar kills, the other change on Cedar Mountain since the 1970 s is that California condors (Gymnogyps californianus Shaw) have begun scavenging lamb carcasses. Our results indicate that increasing populations of cougars, black bears, and condors have complicated the task of protecting lambs from predators.
\end{abstract}

\section{Resumen}

Las pérdidas de corderos debido a la depredación han oscilado históricamente entre 4 a $8 \%$ en el oeste de Estados Unidos pero la mayoría de estos datos tienen más de 30 años. Repetimos un estudio de depredación con ovejas que se condujo entre 1972 y 1975 en Cedar Mountain, en Utah para determinar cómo han cambiado las tasas de depredación en las últimas tres décadas. El tamaño de los potreros y los hatos fueron similares (1730 corderos) entre nuestro estudio (2006 y 2007) y el estudio anterior. Además, el $40 \%$ de los ganaderos en nuestro estudio también participaron en el estudio anterior. Durante 2006 y 2007 , la pérdida total de corderos de Cedar Mountain fue 5.8\%, debido a diferentes causas en comparación de $9.5 \%$ durante la década de 1970. Los depredadores fueron responsables del $87 \%$ de todas las pérdidas verificadas en nuestro estudio contra $83 \%$ de las pérdidas durante 1970. Se estimó que el 4.9\% de todos los corderos de Cedar Mountain fueron matados por predadores durante nuestro estudio, comparado con $7.9 \%$ durante 1970. En nuestro estudio, los coyotes (Canis latrans Say) fueron responsables del $67 \%$ de los corderos depredados, mientras que los pumas (Felis concolor Linnaeus) 31\%, y los osos negros (Ursus americanus Pallas) el 2\%. Durante la década de 1970, los coyotes mataron a $98 \%$ de todos los corderos depredados, pumas un $2 \%$, y los osos a $0 \%$. Además del aumento en las muertes por los pumas, el otro cambio en Cedar Mountain desde la década de 1970 es que los cóndores (Gymnogyps californianus Shaw) de California han comenzado a consumir los cadáveres de los corderos. Nuestros resultados indican que las poblaciones cada vez mayores de los pumas, osos negros y cóndores han complicado la tarea de proteger a los corderos de depredadores.

Key Words: black bears, Canis latrans, condors, cougars, coyotes, Felis concolor, Gymnogyps californianus, predation on lambs, sheep depredation, Ursus americanus

\section{INTRODUCTION}

The sheep ranching industry throughout the United States has experienced a continual decline over the past six or seven decades. During 2008, sheep numbers were just over six million nationwide, only $11 \%$ of the 54 million sheep reported around the peak of the industry during the early 1940s. Sheep populations in the state of Utah have mirrored the nationwide downward trend of the industry; during 2007 , they stood at $9 \%$

Research was funded by Utah's Cedar Mountain Science Initiative and the Utah Agricultural Experiment Station

Correspondence: Michael R. Conover, Wildland Resources Dept, Utah State University, Logan, UT 84322-5230, USA. Email: mike.conover@usu.edu

Manuscript received 6 December 2009; manuscript accepted 6 June 2010 of their historical peak production (US Department of Agriculture National Agricultural Statistics Service [USDA, NASS] 2008). Numerous factors have contributed to the decline of sheep ranching, including a decrease in lamb and wool prices, an increase in labor and operating costs, and competition from foreign imports (Parker and Pope 1983; Jones 2004). However, economic losses due to predation have been the primary reason cited for abandoning sheep operations by ranchers in Utah (Gee et al. 1977) and nationwide (Parker and Pope 1983; Jones 2004; Landivar 2005; USDA, NASS 2005). In the United States, predation losses account for $37 \%$ of all sheep losses annually (USDA, Animal and Plant Health Inspection Service [APHIS] 2007) at an estimated cost of $\$ 18$ million during 2005. In addition to depredation losses, $\$ 10$ million were spent in nonlethal predator control measures in 2005 (USDA, NASS 
2005), and millions more were spent for lethal predator control measures at federal, state, and individual levels of management.

From 1972 to 1975, a study of sheep losses to predation was conducted on Cedar Mountain, which is near Cedar City, Utah, to determine the causes and magnitude of sheep losses in the area. The results of this study were published in a series of papers (Bowns et al. 1973; Davenport et al. 1973; Bowns 1975, 1976; Taylor et al. 1979; Wade and Bowns 1985). The study sampled herds from 10 sheep ranches typical of those located in southwestern Utah during that time period. We repeated the 1970s study to determine how depredation rates on lambs have changed since the earlier study. Henceforth, we will refer to the study we replicated as "the prior study" or "during the 1970s" to distinguish between results from our study and the prior one. We hypothesized that current depredation rates might differ from the prior study because predator densities and sheep husbandry practices have changed since the 1970s. Also, California condors (Gymnogyps californianus Shaw) recently have become numerous on Cedar Mountain, but they were absent during the earlier study. Because these birds are efficient at locating and scavenging carcasses, we hypothesized that their presence would force predators to kill lambs more frequently because predators were no longer able to return to a kill site at a later date to scavenge the carcass.

\section{METHODS}

\section{Study Area}

To provide a comparison between our data and those collected during the prior study, we utilized sheep herds that were located in the same area where sheep herds were studied from 1972 to 1975 (Taylor et al. 1979). Our study area was located on a high-elevation plateau known as Cedar Mountain, which was located near Cedar City, Utah (Fig. 1). The study area was approximately 16850 ha and was composed entirely of privately owned land. Land within the study area was utilized primarily for grazing of sheep both during the prior study and the present study. Cattle rarely are grazed on Cedar Mountain due to the abundance of tall larkspur (Delphinium exaltatum Aiton), a plant toxic to cattle but not sheep. The sheep bands we followed were rotated among pastures that ranged in size from 81 ha to 445 ha; many of these pastures were the same ones used in the prior study. Elevations of grazing pastures ranged from $2400 \mathrm{~m}$ to $2900 \mathrm{~m}$. Terrain was rolling hills and meadows frequently broken by cliffs and canyons. Large flows of volcanic rock also were found throughout the study area. Soil types included Abela cobbly loam, red butte very gravelly loam, and Ocanbee extremely cobbly loam (USDA, Natural Resources Conservation Service [NRCS] 2010).

Vegetative cover varied from dense stands of quaking aspen (Populus tremuloides Michx.), sage-brush (Artemisia tridentata Nutt.), and Gambel oak (Quercus gambelii Nutt.) to grasscovered meadows. Vegetation cover, plant communities, habitats, and land use were similar during our study and the prior study. Cedar Mountain was remote enough that there has been little human development since the 1970s except for the construction of some summer cabins. We used a USDA, NRCS Snotel weather station that was located on Cedar Mountain to

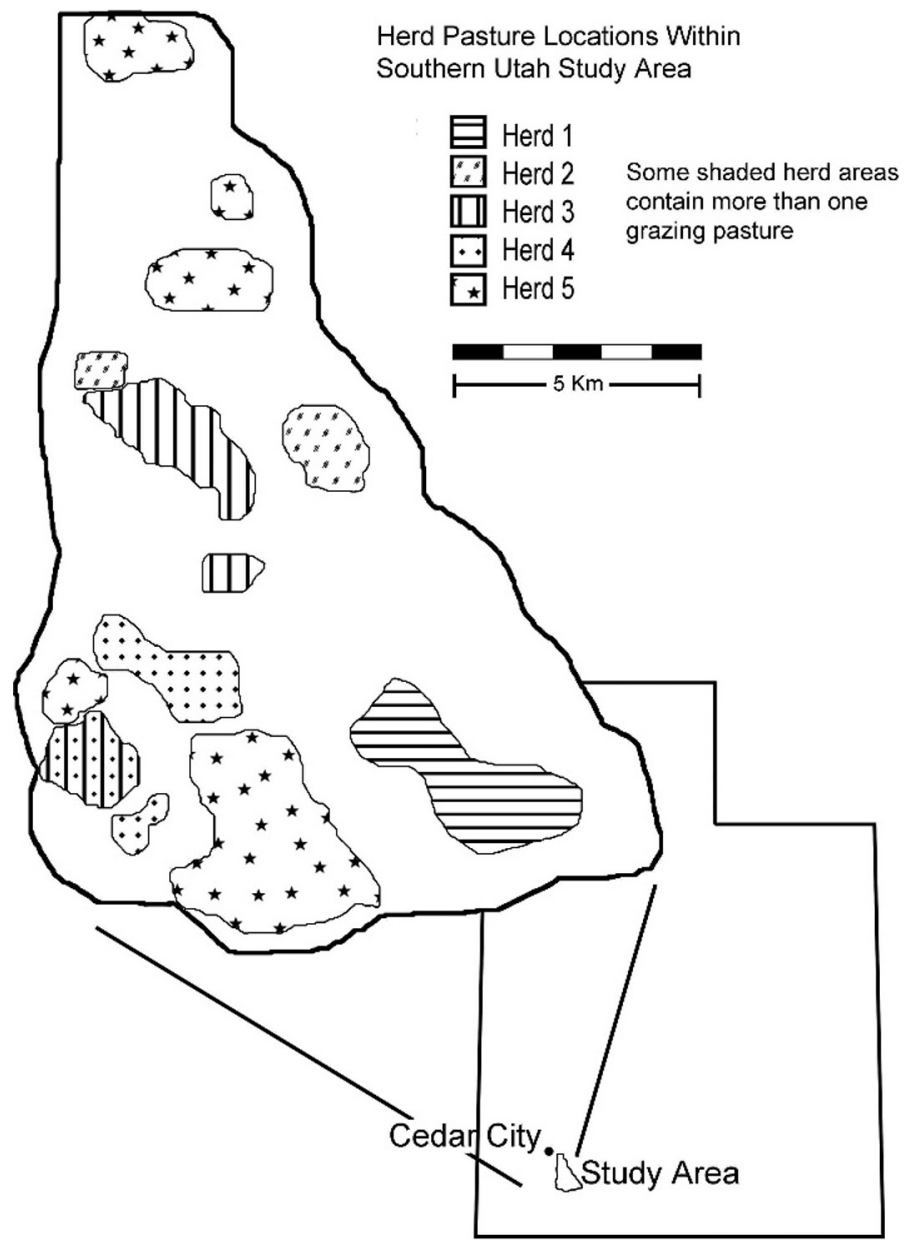

Figure 1. Location of study area in Utah and herd pastures within the study area. Multiple pastures and sheep bands can be located within a single shaded area.

monitor snowfall and precipitation during our study. Snowfall on Cedar Mountain was $82 \%$ of normal during 2006 and $79 \%$ of normal during 2007. Average precipitation on Cedar Mountain was $86 \%$ of normal during spring and summer of 2006 and $72 \%$ during spring and summer of 2007.

\section{Methods}

We monitored five sheep herds during the 2006 summer grazing season and four herds during 2007 using the same methods as Davenport et al. (1973), Taylor et al. (1979), and Wade and Bowns (1985). We contacted sheep ranchers with herds within our study area and asked them if they were willing to participate in our study. All who were willing to participate were included in our study. Two of the five sheep ranchers who agreed to participate in our study also participated in the earlier study. We monitored lambs the entire time they were on Cedar Mountain. Sheep were moved to Cedar Mountain as soon as the area became accessible from winter snow pack (mid-June) and remained there until the fall when weather made access difficult (mid-October).

Each herd on Cedar Mountain was our experimental unit. The prior study also used herds as their experimental units. Herd counts consisted of the number of lambs within each herd (we did not count ewes because predators kill many more lambs than 
ewes and the previous study relied upon the same protocol). Herd counts were made in June by counting the number of lambs during docking or when they were moved onto Cedar Mountain.

Ranchers divided their large herds into two or more smaller bands to aid in herd management and alleviate grazing pressure on pastures. Entire herds of sheep were never together during the summer range season. For the purpose of our research, we used the term herd to represent the entire sheep population under control of one ranching operation and the term band to represent a subunit of a herd. All bands contained both ewes and lambs.

Pastures were too large to search for carcasses over their entire extent; instead, we conducted searches using circular or crisscrossing patterns. We initiated searches for dead animals at the bed ground because earlier studies had reported that predation of sheep typically occurred at night in close proximity to bed grounds (Davenport et al. 1973). We expanded our searches outward from the bed ground and focused on sheep trails and ravines where sheep might have been killed or dragged by predators. Ranchers participating in our study confirmed that they found most dead lambs in these locations. We searched areas within $0.5 \mathrm{~km}$ of the bed grounds on foot and more distant parts of pastures with all-terrain vehicles or binoculars. We located carcasses directly and by watching scavenging birds. We searched pastures experiencing high rates of predation daily and other pastures every other day. We frequently contacted sheep herders and ranchers to determine if they knew of sheep carcasses that we had not detected.

Similar to the earlier study on Cedar Mountain, we necropsied all carcasses according to standards established by Wade and Bowns (1985) to determine whether cause of death was due to predators or whether predators only had scavenged the carcass. When cause of death was not apparent, we skinned the carcasses and searched for signs of subcutaneous hemorrhaging. Bleeding from wounds indicated that the lamb was killed by predators (i.e., wounds occurred while the lamb was still alive), and the absence of blood indicated that the dead sheep had been scavenged by predators after it had died from other causes. Wound marks, pattern of consumption, and distinctive predation signs (e.g., predator tracks or covering the carcass with debris) were used to identify which predator species was responsible for the kill. We photographed carcasses to verify evidences of predation and aid in comparisons among predation incidents. We assigned a necropsy number to each carcass and marked its location using a global positioning system. We noted whether each dead sheep was either a ewe or lamb and whether the cause of death was predatory, nonpredatory, or unknown. Because some carcasses were dismembered and scattered at the time of predation or by subsequent scavenging, all major parts of the carcass, including skeleton and fleece, were sprayed with paint to avoid double counting a carcass that we had already discovered.

We counted the number of golden eagles (Aquila chrysaetos Linnaeus), turkey vultures (Cathartes aura Linnaeus), common ravens (Corvus corax Linnaeus), and California condors scavenging on lamb carcasses. We also monitored how often different birds scavenged a carcass by their characteristic feeding method of feeding. Vultures and ravens peck out the eyes followed by pecking a small hole in the patch right under the front leg where there is little or no wool. They then pull out and consume a small amount of the softer internal organs (e.g., lungs or liver). In contrast, condors pull the wool off the carcass (this was one of the major indicators condors had been there) and open the entire body cavity. Usually condors consumed all of the internal organs. If it was a fresh kill and there were more than 2-3 condors present, they also consume most of the muscle tissue; in contrast, vultures and ravens normally ate little muscle tissue.

Lamb losses for individual herds were classified as 1) losses from all causes, 2) verified losses, 3) verified predator kills, and 4) estimated losses to predators. Lamb losses from all causes were the difference between the lamb count when a sheep herd was placed on Cedar Mountain during June and the final count when they were transported off the mountain during October. Verified losses were the number of lamb carcasses that were discovered by us, herders, or ranchers. Verified predator kills were the number of verified losses that we could identify as predator kills by necropsy. Lambs that were attacked and died later or were unmarketable due to predator-inflicted injuries and subsequently removed from the herd were included in verified predator kills. Estimated losses to predators were the number of lambs that we estimated to have been killed by predators. This value was calculated by multiplying the total number of lamb losses by the proportion of verified lamb losses that were verified as predator kills. This is the same formula used by Taylor et al. (1979) and Wagner and Conover (1999) and is based on the assumption that verified losses are a random sample of all losses.

We used unpaired Student's $t$ tests to compare losses during 2006 to 2007 and to compare losses in herds attended by human herders to unattended herds. The prior study calculated lamb losses by adding all of the lambs missing from any of the herds and dividing this number by the total number of lambs in the herds (Davenport et al. 1973). We followed the same method when we compared our results to those from the prior study. When we compared losses between 2006 and 2007, we calculated a loss value for each herd and then determined the mean and standard error for all herds.

Numbers of predators removed from Cedar Mountain during winter aerial predator control and summer predator control measures were obtained from USDA, Wildlife Services (WS) and participating ranchers. Numbers of cougars and bears taken by sportsmen with hunting permits in the vicinity of the study area were obtained from Utah Division of Wildlife Resources. We have included this information because predator control activities could impact the number of lambs killed by predators. Unfortunately, similar information is unavailable for the prior study.

\section{RESULTS}

\section{Lamb Losses During 2006 and 2007}

Mean number of lambs per herd was 1729 (range 982 to 2817) and was similar between 2006 (mean of 1626) and 2007 (1 857). Each herd lost an average of 100 lambs to all causes or $5.8 \%$ of all lambs (Table 1). In total, 898 lambs were lost both years, and we were able to verify cause of the death for 112 lambs. Lambs died from predation, malnourishment, lightning strikes, and injuries from livestock hauling, automobile collisions, becoming mired in mud, and undetermined causes. The greatest source of mortality was predation; it accounted for 
Table 1. Herd size (number of lambs upon arrival at Cedar Mountain, Utah), total number of lambs lost to all causes (difference in the number of lambs brought onto Cedar Mountain in the spring and taken off by the fall), number of dead lambs we located (verified losses), number of lambs that we verified as predator kills, estimated number of lambs killed by predators, and use of human herders and guard dogs during 2006 and 2007 (data were not collected on herd 2 during 2007).

\begin{tabular}{|c|c|c|c|c|c|c|c|}
\hline Year-herd & $\begin{array}{l}\text { Herd } \\
\text { size }\end{array}$ & $\begin{array}{c}\text { Lambs } \\
\text { lost to al } \\
\text { causes }\end{array}$ & $\begin{array}{l}\text { I Verified } \\
\text { losses }\end{array}$ & $\begin{array}{l}\text { Verified } \\
\text { predator } \\
\text { kills }\end{array}$ & $\begin{array}{l}\text { Estimated } \\
\text { losses to } \\
\text { predators }\end{array}$ & $\begin{array}{l}\text { Herder } \\
\text { present }\end{array}$ & $\begin{array}{c}\text { Guard } \\
\text { dogs } \\
\text { present }\end{array}$ \\
\hline $2006-1$ & 1080 & 58 & 16 & 15 & 54 & No & No \\
\hline 2006-2 & 982 & 42 & 4 & 1 & 11 & No & No \\
\hline $2006-3$ & 1268 & 13 & 5 & 5 & 13 & Yes & No \\
\hline $2006-4$ & 1939 & 26 & 0 & 0 & 0 & Yes & No \\
\hline $2006-5$ & 2861 & 126 & 17 & 12 & 89 & Yes & No \\
\hline $2007-1$ & 1188 & 79 & 16 & 12 & 56 & No & Yes \\
\hline $2007-3$ & 1510 & 235 & 20 & 18 & 213 & No & No \\
\hline $2007-4$ & 1912 & 116 & 5 & 5 & 116 & Yes & No \\
\hline $2007-5$ & 2817 & 203 & 29 & 29 & 203 & Yes & No \\
\hline Total & 15557 & 898 & 112 & 97 & 755 & - & - \\
\hline 2006 & 1626 & 53 & 8 & 7 & 33 & - & - \\
\hline 2007 & 1857 & 158 & 18 & 16 & 147 & - & - \\
\hline Both years & 1729 & 100 & 12 & 11 & 84 & - & - \\
\hline
\end{tabular}

$87 \%$ of all verified lamb losses. We estimated that 84 lambs $(4.9 \%)$ per herd were killed by predators.

Lamb losses per herd to all causes during 2006 were $53 \pm 20$ $(\overline{\mathrm{x}} \pm \mathrm{SE})$ lambs per herd and were significantly lower $(t=2.69$, $\mathrm{df}=7, P=0.03)$ than the $158 \pm 36$ lambs per herd during 2007. Verified lamb losses were $8 \pm 3$ lambs per herd during 2006 and $18 \pm 5$ lambs per herd during 2007; these annual losses were not significantly different $(t=1.56, \mathrm{df}=7$, $P=0.16)$. Verified predator kills were $7 \pm 3$ lambs per herd during 2006 and $16 \pm 6$ lambs per herd during 2007. These losses were not significantly different between years $(t=1.68$, $\mathrm{df}=7, P=0.14)$ but estimated lamb losses to predators differed $(t=3.00, \mathrm{df}=7, P=0.02)$ between 2006 (mean $=33$ \pm 17 lambs per herd) and the next year (mean $=47 \pm 37$ lambs per herd).

We were able to determine predator species responsible for killing 97 lambs; coyotes killed 67\%, cougars killed 31\%, and black bears killed 2\%. During 2006, coyotes killed 13 lambs, cougars killed 18, and black bears killed 2. During 2007, coyotes and cougars killed 52 and 12 lambs, respectively. There were no verified black bear depredations during 2007.

Predator kills were widely dispersed among pastures. During 2006, coyote kills were found in five pastures, cougar kills in four pastures, and the black bear kills in two. During 2007, 14 pastures had confirmed coyote kills, and five pastures had confirmed cougar kills. Thirty-two pastures were grazed by sheep during our study; only eight of them did not have a verified predator kill.

There were no verified predator kills during our study that could be attributed to a predator species other than coyotes, cougars, and black bears. We observed golden eagles scavenging on six carcasses, but in each case where eagles were observed on lamb carcasses, we were able to determine that the kill had been made by a coyote.

\section{Scavenging of Lamb Carcasses During 2006 and 2007}

Based on our observations, about $80 \%$ of the lamb carcasses were scavenged by birds. In addition to golden eagles, we saw scavenging by turkey vultures, common ravens, and California condors. During 2007, we observed condors flying over the study site 16 to 18 times per month and in direct proximity to carcasses 10 to 12 times per month. Approximately $75 \%$ of all lamb carcasses were scavenged by condors; only carcasses located in thick brush or hidden by predators escaped the attention of condors. The scavenging capabilities of condors were impressive; they could almost completely consume a lamb carcass within a couple of hours. On one occasion, we discovered a newly killed lamb that had not been fed on by the predator and before any scavenging birds had arrived. We necropsied the carcass and left to continue our search for carcasses. Upon returning $2 \mathrm{hr}$ later, we observed 19 condors on the ground near the carcass. All that remained of the lamb was part of the fleece, most of the vertebral column, the skull, and three legs. When we returned to the site the next morning, all that remained was part of the fleece.

\section{Lamb Losses by Herd and Husbandry Practices}

We monitored 24 bands of sheep during 2006 and 21 bands during 2007. Bands of sheep ranged in size from 110 to 600 animals with a mean of 353 during 2006 and 363 during 2007. There was no significant difference in the size of sheep bands that experienced predation and bands that did not experience predators $(t=0.71, \mathrm{df}=56, P=0.75)$. Five of nine herds during our study were tended by human herders (Table 1 ). Herds attended by herders were slightly larger $(\overline{\mathrm{x}}=1898$ lambs $)$ than unattended herds ( $\overline{\mathrm{x}}=1517$ lambs). Attended herds were similar to unattended herds in the number of lambs lost to all causes $(t=0.14, \mathrm{df}=7, P=0.89)$, number of verified lamb losses $(t=1.09, \mathrm{df}=7, P=0.31)$, number of verified predator kills $(t=1.01, \mathrm{df}=7, P=0.35)$, and number of estimated lamb losses to predators ( $t=0.09, \mathrm{df}=7, P=0.93$; Table 2$)$. Only one herd used a guard dog to protect their sheep from predators (Table 1). Losses for this herd were similar to the others. This herd, however, was separated into two bands, and all of the losses occurred in the band without the guard dog.

\section{Predator Removal Practices}

USDA, WS removed 27 coyotes during 2006 and 50 coyotes during 2007 from our study area; they did not remove any cougars or bears. Most ranchers carried rifles with them when in their pastures, but none reported killing any predators. The entire study area was posted "no trespassing" so we do not think recreational hunters killed many predators.

The study area was a small part of Utah Division of Wildlife Resources' Predator Management Unit 29 (Zion), which encompasses $>4000 \mathrm{~km}^{2}$. Within this unit, 17 cougars were killed by recreational hunters during both 2006 and 2007 (Hersey et al. 2008). However, these cougars were not killed in the vicinity of our study area. Although bear permits were issued for Unit 29 during both 2006 and 2007, no bears were killed by hunters.

\section{Changes in Lamb Losses Since the 1970s}

During the prior study, an average of 165 lambs per herd was lost annually or $8 \%$ of all lambs observed during the $4 \mathrm{yr}$ of 
Table 2. Herd size (number of lambs upon arrival at Cedar Mountain, Utah), number of lambs lost to all causes (difference in the number of lambs brought onto Cedar Mountain in the spring and taken off by the fall), number of lambs that were verified as a predator kill, estimated number of lambs killed by predators during 1972 by Taylor et al. (1979), and information on the use of human herders and guard dogs (herd data were unavailable for 1971, 1973, and 1974).

\begin{tabular}{|c|c|c|c|c|c|c|}
\hline Herd & $\begin{array}{l}\text { Herd } \\
\text { size }\end{array}$ & $\begin{array}{l}\text { Lambs lost to } \\
\text { all causes }\end{array}$ & $\begin{array}{l}\text { Verified } \\
\text { predator kills }\end{array}$ & $\begin{array}{l}\text { Estimated losses } \\
s \text { to predators }\end{array}$ & $\begin{array}{l}\text { Herder } \\
\text { present }\end{array}$ & $\begin{array}{c}\text { Guard dogs } \\
\text { present }\end{array}$ \\
\hline 1 & 1100 & 250 & 46 & 182 & No & No \\
\hline 2 & 1538 & 147 & 25 & 107 & Yes & Yes \\
\hline 3 & 1679 & 57 & 15 & 41 & Yes & Yes \\
\hline 4 & 1074 & 112 & 2 & 82 & No & No \\
\hline 5 & 1652 & 136 & 5 & 99 & Yes & Yes \\
\hline 6 & 2316 & 182 & 13 & 132 & No & No \\
\hline 7 & 1859 & 66 & 15 & 48 & Yes & Yes \\
\hline 8 & 3478 & 460 & 102 & 335 & No & No \\
\hline 9 & 820 & 72 & 29 & 52 & No & No \\
\hline 10 & 1782 & 167 & 17 & 122 & Yes & Yes \\
\hline Mean & 1730 & 165 & 27 & 120 & - & - \\
\hline
\end{tabular}

that study (Tables 2 and 3). During our study, predators were responsible for $87 \%$ of all verified lamb losses; Taylor et al. (1979) found that from 1972 through 1975, predators were responsible for $83 \%$ of all verified lamb losses.

Coyotes were responsible for most $(98 \%)$ of the predator kills during the previous study. Black bears and cougars combined never accounted for more than $11 \%$ of the verified predator kills during the previous study. During some years of the prior study, there were no losses that could be attributed to cougars or bears. During our study, coyotes were responsible for $67 \%$ of the depredated lambs, cougars for $31 \%$, and black bears for $2 \%$.

\section{DISCUSSION}

The greatest difficulty associated with this type of study is accounting for missing lambs (Bowns et al. 1973). Even though we constantly had two or three people searching for missing lambs, we were only able to locate $17 \%$ and $11 \%$ of missing lambs during the $2 \mathrm{yr}$ of our study. Bowns (1975) reported his rates of locating missing lambs on Cedar Mountain for the study years 1972,1973 , and 1974 were $24 \%, 24 \%$, and $36 \%$, respectively. One reason we found a smaller fraction of missing lambs than the prior study was because of the recent occurrence of endangered California condor at the site. These birds were common on Cedar Mountain during our study but were absent during the 1970s. Their scavenging capability was such that little remained of a lamb carcass after being discovered by condors.

Our estimates on the number of lambs killed by predators were based on the proportion of dead lambs that we found (verified losses) that we could identify as being killed by predators (verified predator kills). We made the assumption that this proportion could be extrapolated from verified losses to missing lambs that we could not locate. Likewise, Taylor et al. (1979) assumed that the dead lambs they found (i.e., verified
Table 3. Percent of all lambs brought onto Cedar Mountain in the spring that were lost while on Cedar Mountain to all causes, percent that were verified as a predator kill, and percent that were estimated to have been killed by predators during 1972, 1973, 1974, and 1975 by Taylor et al. (1979) and during 2006 and 2007 by our study. The yearly figures were calculated by combining all herds during the same year into a single unit and determining percent losses based on that one combined unit rather than calculating a separate value for each herd and reporting a mean percent of the separate values.

\begin{tabular}{cccc}
\hline Year & $\begin{array}{c}\text { \% lambs lost } \\
\text { to all causes }\end{array}$ & $\begin{array}{c}\text { \% lambs verified } \\
\text { as a predator kill }\end{array}$ & $\begin{array}{c}\% \text { lambs estimated } \\
\text { as a predator kill }\end{array}$ \\
\hline 1972 & 9.65 & 1.60 & 7.54 \\
1973 & 8.85 & 1.96 & 3.77 \\
1974 & 8.07 & 1.35 & 4.34 \\
1975 & 6.03 & 1.35 & 1.94 \\
2006 & 3.26 & 0.41 & 2.05 \\
2007 & 8.52 & 0.86 & 7.92 \\
\hline
\end{tabular}

losses) were a random sample of all missing lambs, and the consistency of their predator kill data bears this out. During 1972 , they found $24 \%$ of all missing lambs; during 1975 , they intensified their effort to find missing lambs and located $89 \%$ of them. Yet the proportions of verified losses that were killed by predators were similar during both years.

We found that lamb losses to all causes during 2007 and the estimated losses to predators that year were twice as high as during 2006. Simultaneously, sightings of coyotes during WS predator control flights nearly doubled between 2006 and 2007, which would suggest an increase in the overall coyote abundance within the study area (Preston Nowers, USDA, APHIS, WS, personal communication, June 2007). This increase could account at least for part of the increase in lamb losses during the second year of our study. Stoddart et al. (2001) and Sacks and Neale (2007) both found that lamb losses corresponded with changing coyote abundance regardless of natural prey levels.

The lamb losses of $3.3 \%$ that we observed in 2006 and $8.5 \%$ in 2007 were at the lower and upper limits of rates of loss that have been reported elsewhere in the western United States (Wagner 1988). All of the ranchers involved in our study suggested that lamb losses during 2007 were higher than their typical losses. One rancher mentioned the fact that he was having sheep killed in a pasture where he rarely had predator problems over the prior $30 \mathrm{yr}$ (Tom Williams, Cedar Mountain sheep rancher, personal communication, July 2007). Snowfall and rainfall were remarkably similar during 2006 and 2007. Hence, we do not believe that weather or range conditions can account for differences in lamb losses between 2006 and 2007.

Nonpredatory lamb losses varied little between the $2 \mathrm{yr}$ of our study and made up $1 \%$ of the total number of lambs on Cedar Mountain each year. Taylor et al. (1979) reported the same pattern of consistency with nonpredatory losses making up $1 \%$ of the total lamb crop each year for the summer range season. The consistency of nonpredatory losses between the two studies lends veracity to our estimate of total losses to predators and our observation that the variation in losses between years can be explained by variation in annual predation rates. 
Annual lamb losses for the $2 \mathrm{yr}$ of our study were 100 lambs per herd or $5.9 \%$ of all lambs. These losses were similar to the 165 lambs per herd or $9.7 \%$ of all lambs observed during the $4 \mathrm{yr}$ of the previous study (Tables 2 and 3). During our study, predators were responsible for $87 \%$ of all verified lamb losses; Taylor et al. (1979) found that from 1972 through 1975, predators were responsible for $83 \%$ of the verified losses.

Although coyotes were responsible for most of the predator kills during both our study and the previous study, the greatest difference in the results between our study and the previous one was the increased number of kills by cougars and black bears during our study. Cougar kills accounted for $55 \%$ of the verified predator kills in 2006 and 19\% in 2007. Black bears were responsible for $6 \%$ of verified kills during 2006, but none occurred during 2007. In contrast, bears and cougars combined never accounted for more than $11 \%$ of the verified predator kills during the previous study.

One potential reason for the increase in kills by black bears and cougars is that their populations during our study were probably higher than in the 1970s (M. Bodenchuk, Utah director, USDA, WS, personal communication, March 2010). Until 1968, both species were unprotected in Utah, and during the 1970s an unlimited number of hunting permits were issued for both species. During our study, the hunting of black bears and cougars was closely regulated with only a limited number of hunting permits being granted yearly.

California condors are an endangered species, and none were reported on Cedar Mountain during the prior study. Following a successful captive breeding program, California condors were released in Arizona during 1996. During our study, the Arizona population had increased to 55 birds. According to biologists with the Peregrine Fund who oversee the restoration effort of the California condor, 42 of the 55 condors in the Arizona population spent summers foraging on Cedar Mountain. Peregrine Fund biologists believed that the condors were attracted to Cedar Mountain because the dead sheep and lambs provided an ample and consistent food supply for them. Biologists also noted that Cedar Mountain's rugged topography created numerous updrafts and thermals that were ideal for soaring condors (Eric Weis, Peregrine Fund, personal communication, July 2007; Peregrine Fund 2010).

California condors are efficient scavengers. During our study, condors located about $75 \%$ of the lamb carcasses on Cedar Mountain. Condors can completely scavenge a carcass within a few hours such that little of it remains after they are finished. Their presence on Cedar Mountain during our study limited the ability of predators to return to a prior kill and scavenge the carcass at a later date. Hence, predators during our study might have been forced to kill lambs more frequently than predators did during the prior study when condors were absent.

Methods used to remove coyotes had changed little since the prior study. During the 1970s, aerial shooting, leg-hold traps, snares, and M-44s were the primary methods used by WS to kill coyotes (Wagner 1988). During our study, these methods remained WS's primary control methods. Hence, any differences in the number of lambs killed by predators cannot be attributed to either the introduction of a new method or the loss of a traditional method since the prior study.

Sheep ranching operations within our study area have shown resilience to the general declines the sheep industry has experienced over the past several decades. Mean herd sizes for our study (1729 lambs) were almost identical to the mean herd size of 1730 during 1972 (Tables 1 and 2). Most of the pastures in the study area have been in use since at least the early 1900s, and their boundaries have changed little since the previous study took place in the 1970s. Five of nine herds during our study were tended by human herders. This proportion was similar to the prior study when five out of ten herds used herders. What has changed since the 1970s has been the duties of sheep herders (T. Williams, C. Jones, and J. Cornelius, Cedar Mountain ranchers, 2007, personal communication, July 2007). During our study, herders were utilized primarily to move herds between pastures and into undergrazed portions of pastures, maintain fences, and check for dead sheep, with fence maintenance occupying most of the herder's time. Predator control appeared to be of a lower priority to most herders (personal observation). None reported ever killing a predator although most kept a rifle in camp. Because of the intermittent presence of herders with any given sheep band, those herds with herders suffered similar losses to predators as those without herders during our study. In contrast, Davenport et al. (1973) reported that during the earlier study, herders who remained constantly with the sheep had a measurable impact on predation rates in the herds they attended.

Another change was in the use of guard dogs. Half of the herds during the 1970s used guard dogs to protect sheep from predators (Table 2). Davenport et al. (1973) as well as others (Green et al. 1984; Conover 1998, 2002) have suggested that guard dogs were an effective deterrent against predators, as have many others. During our study, only one herd was protected by guard dogs and that herd was guarded by them only during the second year of our study. The lambs in that herd were divided into two bands and only one of those bands was protected by guard dogs. All of the verified losses with that herd were in the band without a guard dog. Yet, if guard dogs were effective, then their use should have increased since the 1970s. Instead, their use has declined. We assume that the decline in guard dog use by ranchers is because local ranchers believe that the number of lambs saved by guard dogs does not justify the cost of guard dogs. We do not know whether this lack of cost-effectiveness resulted because guard dogs did not deter predators or were too expensive to maintain.

\section{IMPLICATIONS}

Livestock producers, land managers, and wildlife biologists need accurate information on livestock losses to predators and how current predation rates compare to those during earlier periods. We found that predation losses among sheep herds in southwestern Utah during 2006 and 2007 were similar to losses in the same area during the 1970s. Most depredated lambs during our study were killed by coyotes as were almost all depredated lambs during the prior study. Cougars and black bears killed several lambs during our study, but few during the previous study. California condors are efficient scavengers, and they were foraging on Cedar Mountain during our study but were absent during the prior study. Our results indicate that increasing populations of cougars, black bears, and condors have complicated the task of protecting lambs from predators. 


\section{ACKNOWLEDGMENTS}

We thank Frederick F. Knowlton, Susan Durham, Daniel Goold, Richard Brooksby, and Kenneth Richards for their help with this study. Additionally we thank Mike Clark, Jared Cornelius, David Hulet, Craig Jones, and Tom Williams for allowing us to monitor their sheep.

\section{LITERATURE CITED}

Bowns, J. E. 1975. Damage assessment studies in Utah [unpublished paper]. Cedar City, UT, USA: Southern Utah University. 2 p.

Bowns, J. E. 1976. Field criteria for predator damage assessment. Utah Science $36: 26-30$.

Bowns, J. E., J. W. Davenport, J. P. Workman, D. B. Nielsen, and D. D. Dwyer. 1973. Determination of cause and magnitude of sheep losses in southwestern Utah. Utah Science 34:35-37, 52.

Conover, M. R. 1998. Perceptions of American agricultural producers about wildlife on their farms and ranches. Wildlife Society Bulletin 26:597-604.

Conover, M. R. 2002. Resolving human-wildlife conflicts: the science of wildlife damage management. Boca Raton, FL, USA: Lewis Brothers. 418 p.

Davenport, J. W., J. E. Bowns, and J. P. Workman. 1973. Assessment of sheep losses to coyotes - a problem to Utah sheepmen-a concern of Utah researchers. Logan, UT, USA: Utah Agricultural Experiment Station Research Report 7. $17 \mathrm{p}$.

Gee, C. K., R. S. Magleby, D. B. Nielsen, and D. M. Stevens. 1977. Factors in the decline of the western sheep industry. Washington, DC, USA: Natural Resources Economics Division, Economic Resources Services, USDA Agricultural Economic Report Number 377. $31 \mathrm{p}$.

Green, J. S., R. A. Woodruff, and T. T. Tueller. 1984. Livestock-guarding dogs for predator control: costs, benefits, and practicality. Wildlife Society Bulletin 12:44-50.

Hersey, K. R., H. H. Bernales, and K. Bunnell. 2008. Utah cougar annual report 2006 and 2007. Salt Lake City, UT, USA: Utah Division of Wildlife Resources Publication No. 08-35. $78 \mathrm{p}$.

Jones, K. G. 2004. Trends in the U.S. sheep industry. Washington, DC, USA: US Department of Agriculture, Agriculture Information Bulletin Number 787. 36 p.
Landivar, L. A. R. 2005. Econometric model of the U.S. sheep and mohair industries for policy analysis [dissertation]. College Station, TX, USA: Texas A\&M University. $90 \mathrm{p}$.

Parker, C. F., and A. F. Pope. 1983. The U.S. sheep industry: changes and challenges. Journal of Animal Science 57:75-99.

Peregrine Fund. 2010. The Peregrine Fund and World Center for Birds of Prey. Available at: http://www.peregrinefund.org/archivednotes. Accessed 23 March 2010.

Sacks, B. N., and J. C. C. Neale. 2007. Coyote abundance, sheep predation, and wild prey correlates illuminate Mediterranean trophic dynamics. Journal of Wildlife Management 71:2404-2411.

Stoddart, L. C., R. E. Griffiths, and F. F. Knowlton. 2001. Coyote responses to changing jackrabbit abundance affect sheep predation. Journal of Range Management 54:15-20.

Taylor, R. G., J. P. Workman, and J. E. Bowns. 1979. The economics of sheep predation in southwestern Utah. Journal of Range Management 32:317-321.

[USDA, Aphis] US Department of Agriculture, Animal and Plant Health Inspection SERvice. 2007. Highlights of the sheep and lamb predator death loss in the United States, 2004 Report. Washington, DC, USA: Animal and Plant Health Inspection Service, Wildlife Services September Info Sheet. 2 p.

[USDA, NASS] US Department of Agriculture, National Agricultural Statistics ServicE. 2005. Sheep and goats death loss. Washington, DC, USA: National Agricultural Statistics Service. $18 \mathrm{p}$.

[USDA, nass] US Department of Agriculture, National Agricultural Statistics Service. 2008. Agricultural statistics database. Sheep and lamb state and county statistics. Available at: http://www.nass.usda.gov. Accessed 14 July 2008.

[USDA, nRCS] US Department of Agriculture, Natural Resources Conservation Service. 2010. Web soil survey. Available at: http://websoilsurvey.nrcs.usda. gov. Accessed 1 June 2010.

Wade, D. A., AND J. E. Bowns. 1985. Procedures for evaluating predation on livestock and wildlife. College Station, TX, USA: Texas Agricultural Experiment Station, Texas A\&M University Bulletin B-1429. 42 p.

WaGneR, F. H. 1988. Predator control and the sheep industry. Claremont, CA, USA: Regina. 230 p.

Wagner, K. K., AND M. R. Conover. 1999. Effect of preventive coyote hunting on sheep losses to coyote predation. Journal of Wildlife Management 63:606-612. 